$\xi=-1$

\title{
Experimental study on potential use of fly ash and GGBS from Jaipur plants in developing a self-compacting concrete
}

\author{
Sushree Sangita Rautray ${ }^{1 *}$, Manas Ranjan Das ${ }^{1}$ \\ ${ }^{1}$ Department of Civil Engineering Institute of Technical Education and Research Siksha 'O' Anusandhan Deemed to be University \\ Bhubaneswar, Odisha \\ *Corresponding author E-mail: manasdas@soa.ac.in
}

\begin{abstract}
Self-Compacting Concrete (SCC) is becoming a popular choice in concrete industries due to its filling ability in congested reinforcement and its auto compacting nature. In the present work, an attempt has been made to investigate the properties of fresh and hardened concrete made by partial replacement of cement by fly ash and ground granulated blast furnace slag (ggbs) in different percentages. The essential properties of freshly prepared concrete like flowability, passing ability, filling ability are determined by slump flow test, slump flow T50cm, V-funnel, J-ring and L-box test. The values are found to satisfy EFNARC guidelines. Tests have also been conducted to assess and analyze the properties of hardened concrete such as compressive strength, split tensile strength and flexural strength. Thus an attempt has been made to develop a formulation of an economically feasible and environment friendly self-compacting concrete.
\end{abstract}

Keywords: Fly Ash; Ground Granulated Blast Furnace Slag; Self-Compacting Concrete.

\section{Introduction}

Self-compacting concrete is the type of concrete, which is placed without vibration and has the ability to flow under its own weight completely filling the voids, gaps, edges, formworks and achieves full compaction even in the presence of congested reinforcement. Self-Compacting Concrete (SCC) is a compound system that is usually proportioned with one or more additions of chemical admixtures. Modern application of SCC is focused on high performance and uniform quality Domone (2007). Fly ash and ggbs are two waste products produced from thermal power plant and steel industries. 180 billion metric tons of coal is reserved in

India so nearly $90 \%$ of thermal power plant utilizes coal to produce electricity. At present nearly 185 million coal ash is produced in India and it will double itself in next two decade.

Likewise Ground granulated blast furnace slag (ggbs) is also produced in large amount. Due to enormous production of these waste materials, it needs to be used for various proposals to save the environment. Different authors have investigated the use of fly ash, ggbs, silica fume, red mud etc to form SCC (Cengiz 2005; Domone P, 2007, Xie et al., 2002; Sowmya and Praveen, 2017). In continuation of this, Khatib (2008) investigated on SCC using fly ash and ggbs with partial replacement of cement. Different
Percentage of fly ash and ggbs is replaced for cement to find the compressive, tensile and flexural strength. Mustafa, S. and Yaman, (2007).Transport and mechanical properties of self-consolidating concrete with high volume fly ash. In the present work, an attempt has been made to develop a mix design for an eco-friendly self-compacting concrete using fly ash and ground granulated blast furnace slag which will satisfy EFNARC guidelines.

\section{Materials}

The OPC 43 grade cement conforming to IS: 8112-1989 was bought from a local supplier in bulk from Bhubaneswar; Odisha. The fine aggregates (FA) were brought from the Kathojodi River, Bhubaneswar, Odisha and confirming to zone III. The coarse aggregates were brought from the local supplier of Bhubaneswar. The aggregate size used is $12.5 \mathrm{~mm}$ and $19 \mathrm{~mm}$. In this project superplasticizer master glenium sky 8630 was being used to prepare the SCC as per IS: 9103-1999. The fly ash and ggbs used in the present investigation were collected from Jindal power plant, Jajpur road. The test on fly ash was carried out as per IS 1727-1967.

Table 1: Physical Properties of Cement

\begin{tabular}{|c|c|c|}
\hline \multirow[t]{2}{*}{ Characteristics } & \multicolumn{2}{|r|}{ OPC-43 grade } \\
\hline & \multirow{2}{*}{\multicolumn{2}{|c|}{$\begin{array}{l}\text { Test value } \\
\text { NA }(\%)\end{array}$}} \\
\hline Normal consistency & & \\
\hline Specific gravity & 3.15 & 3.15 \\
\hline Fineness (\%) & 1.33 & 10 \\
\hline Initial setting time & 2 hours 40 minutes & $30(\min )$ \\
\hline Final setting time & 5 hours 30 minutes & $600(\max )$ \\
\hline 3days compressive & 24.2 & 23 (min) strength (Mpa) \\
\hline 7 days compressive & 34.8 & 33 (min) strength (Mpa) \\
\hline 28 days compressive & 44.3 & $43(\mathrm{~min})$ \\
\hline
\end{tabular}


strength (Mpa)

Table 2: Properties of Natural Fine Aggregate and Course Aggregate

\begin{tabular}{lll}
\hline Characteristics & Test value (as per IS: 383-1970) & Coarse Aggregate \\
& Fine Aggregate & 6.8 \\
Fineness modulus & 2.40, Zone III & 2.87 \\
Specific gravity & 2.63 & $0.845 \%$ \\
Water absorption & $1.01 \%$ & Nil \\
Free surface moisture & $0.90 \%$ & \\
\hline
\end{tabular}

Table 3: Chemical Composition of Fly Ash

\begin{tabular}{|c|c|c|c|}
\hline Type & $\begin{array}{l}\text { Fly ash (Present study) } \\
(\%)\end{array}$ & ASTM Requirement C-618 Class F (\%) & I.S. Specifications (\%) \\
\hline $\mathrm{SiO}_{2}$ & 56.04 & -- & 35 (minimum) \\
\hline $\mathrm{Al}_{2} \mathrm{O}_{3}$ & 33.85 & -- & \\
\hline $\mathrm{Fe}_{2} \mathrm{O}_{3}$ & 3.90 & -- & \\
\hline $\begin{array}{l}\mathrm{SiO}_{2}+\mathrm{Al}_{2} \mathrm{O}_{3} \\
+\mathrm{Fe}_{2} \mathrm{O}_{3}\end{array}$ & 93.84 & 70.00 minimum & 70.0 (minimum) \\
\hline $\mathrm{CaO}$ & 0.73 & -- & \\
\hline $\mathrm{MgO}$ & 0.68 & 5.00 maximum & 5.0 (maximum) \\
\hline $\mathrm{K}_{2} \mathrm{O}$ & 1.22 & & \\
\hline $\mathrm{Na}_{2} \mathrm{O}$ & 0.19 & 1.50 Maximum & 1.5 (maximum) \\
\hline $\mathrm{TiO}_{2}$ & 2.69 & & \\
\hline $\mathrm{MnO}_{2}$ & 0.31 & -- & \\
\hline $\mathrm{SO}_{3}$ & 0.05 & 5.00 maximum & 3.0 (maximum) \\
\hline L.O.I. $\left(900^{\circ} \mathrm{C}\right)$ & 1.40 & 6.00 maximum & 5.0 (maximum) \\
\hline
\end{tabular}

Table 4: Chemical Composition of GGBS

\begin{tabular}{lll}
\hline Sl. no. & Parameters & Concentration in ggbs (\%) \\
\hline 1 & $\mathrm{SiO} 2$ & 40 \\
2 & $\mathrm{AlO} 3$ & 13.5 \\
3 & $\mathrm{CaO}$ & 39.2 \\
4 & $\mathrm{MgO}$ & 3.6 \\
5 & $\mathrm{Fe} 2 \mathrm{O} 3$ & $1.8 \%$ \\
6 & $\mathrm{SO} 3$ & $0.3 \%$ \\
\hline
\end{tabular}

\section{Mix design methodology}

This project was carried out in 2 phases. In phase I control mix was prepared for SCC using $100 \%$ cement. This phase is divided into two parts where one part SCC was prepared by mixing certain amount of super plasticizer and in other part made without any super plasticizer. In phase II 12 mixes were prepared for SCC by replacing cement with fly ash and ggbs in certain quantity. The first 8 mixes were prepared of $1 \%$ SP with 0.55 water/binder ratio and the last four mixes were prepared of $4 \%$ SP with 0.45 water/ binder ratio. In phase I water to cement ratio is kept constant at 0.45 but in phase II the water to binder percentage kept constant at
0.55 to meet properties of fresh self compacting concrete. The mass of total cementious material was $437 \mathrm{~kg} / \mathrm{m}^{3}$. The detail mix proportions are given in the table below.

Table 5: Mix Identification of Partial Replacement of Cement with Fly Ash and GGBS

\begin{tabular}{|c|c|}
\hline Mix identification & Concrete mix proportion \\
\hline $\mathrm{CM}_{1}$ & Normal SCC mix with $100 \%$ cement $+0 \%$ SP \\
\hline $\begin{array}{l}+w / b=0.45 \\
\text { CM } 2 \\
+w / b=0.45\end{array}$ & Normal SCC mix with $100 \%$ cement $+1 \%$ SP \\
\hline $\begin{array}{l}\text { M1 } \\
+\mathrm{w} / \mathrm{b}=0.55\end{array}$ & SCC With Cement $80 \%$ + Fly Ash $20 \%+1 \%$ SP \\
\hline M2 & SCC With Cement $80 \%+\operatorname{ggbs} 20 \%+1 \% S P+w / b=0.55$ \\
\hline M3 & SCC With Cement $60 \%+$ Fly Ash $40 \%+1 \%$ SP+w $/ b=0.55$ \\
\hline M4 & SCC With Cement $60 \%+$ ggbs $40 \%+1 \% \mathrm{SP}+\mathrm{w} / \mathrm{b}=0.55$ \\
\hline M5 & SCC With Cement $50 \%+$ Fly Ash $50 \%+1 \%$ SP+w $/ b=0.55$ \\
\hline M6 & SCC With Cement $50 \%+$ ggbs $50 \%+1 \% \mathrm{SP}+\mathrm{w} / \mathrm{b}=0.55$ \\
\hline M7 & SCC With Cement $40 \%$ + Fly Ash $40 \%$ + ggbs \\
\hline \multicolumn{2}{|c|}{$20 \%+1 \% \mathrm{SP}+\mathrm{w} / \mathrm{b}=0.55$} \\
\hline M8 & SCC With Cement $40 \%+$ ggbs $40 \%+$ Fly Ash \\
\hline \multicolumn{2}{|c|}{$20 \%+1 \% \mathrm{SP}+\mathrm{w} / \mathrm{b}=0.55$} \\
\hline SM1 & SCC With Cement $50 \%+$ Fly Ash $50 \%+4 \%$ SP+w $/ b=0.45$ \\
\hline SM2 & SCC With Cement $50 \%+$ ggbs $50 \%+4 \% \mathrm{SP}+\mathrm{w} / \mathrm{b}=0.45$ \\
\hline SM3 & SCC With Cement $40 \%+$ Fly Ash $40 \%$ + ggbs \\
\hline \multicolumn{2}{|c|}{$20 \%+4 \% \mathrm{SP}+\mathrm{w} / \mathrm{b}=0.45$} \\
\hline SM4 $40 \%+4 \%$ SP+ & $\begin{array}{l}\text { SCC With Cement } 40 \%+\text { ggbs } 40 \%+\text { Fly Ash } \\
45\end{array}$ \\
\hline
\end{tabular}


Table 6: Mix Proportion of Partial Replacement of Cement with Fly Ash and GGBS

\begin{tabular}{|c|c|c|c|c|c|c|c|}
\hline Mix ID & Cement $\mathrm{Kg} / \mathrm{m}^{3}$ & Fly Ash $\mathrm{Kg} / \mathrm{m}^{3}$ & ggbs $\mathrm{Kg} / \mathrm{m}^{3}$ & $\mathrm{FA} \mathrm{Kg} / \mathrm{m}^{3}$ & $\mathrm{CA} \mathrm{Kg} / \mathrm{m}^{3}$ & W/B Ratio & Super Plasticize r \% \\
\hline$\overline{\mathrm{CM}} 1$ & 437.77 & 0 & 0 & 756.17 & 893.20 & 0.80 & 0 \\
\hline $\mathrm{CM}_{2}$ & 437.77 & 0 & 0 & 756.17 & 893.20 & 0.45 & 1 \\
\hline M1 & 350 & 87.55 & 0 & 756.17 & 893.20 & 0.55 & 1 \\
\hline $\mathrm{M}_{2}$ & 350 & 0 & 87.55 & 756.17 & 893.20 & 0.55 & 1 \\
\hline M3 & 262.66 & 175.10 & 0 & 756.17 & 893.20 & 0.55 & 1 \\
\hline M4 & 262.66 & 0 & 175.55 & 756.17 & 893.20 & 0.55 & 1 \\
\hline M5 & 218.88 & 218.88 & 0 & 756.17 & 893.20 & 0.55 & 1 \\
\hline M6 & 218.88 & 0 & 218.88 & 756.17 & 893.20 & 0.55 & 1 \\
\hline M7 & 175.10 & 175.10 & 87.35 & 756.17 & 893.20 & 0.55 & 1 \\
\hline M8 & 175.10 & 87.35 & 175.10 & 756.17 & 893.20 & 0.55 & 1 \\
\hline $\mathrm{SM}_{1}$ & 218.88 & 218.88 & 0 & 756.17 & 893.20 & 0.45 & 4 \\
\hline $\mathrm{SM}_{2}$ & 218.88 & 0 & 218.88 & 756.17 & 893.20 & 0.45 & 4 \\
\hline SM3 & 175.10 & 175.10 & 87.35 & 756.17 & 893.20 & 0.45 & 4 \\
\hline $\mathrm{SM}_{4}$ & 175.10 & 87.10 & 175.10 & 756.17 & 893.20 & 0.45 & 4 \\
\hline
\end{tabular}

\section{Curing}

The specimens were cured in water under normal temperature and humidity (i.e. from CM1 to SM4). The specimens were kept in water for the days of testing to check its compressive, tensile and flexural strength.

\section{Tests on concrete}

\subsection{Fresh concrete test}

For the initial mix design of SCC all three parameters (i.e. passing ability, filling ability and segregation resistance) of fresh concrete need to be assessed to ensure that all aspects are fulfilled as per EFNARC standards.

Table 7: Properties and Method of Fresh SCC

\begin{tabular}{llll}
\hline Sl. No. & Method & Property & $\begin{array}{l}\text { Typical Range Ac- } \\
\text { cording to EFNARC }\end{array}$ \\
\hline 1 & Slump-flow by & Filling ability & $650-800 \mathrm{~mm}$ \\
2 & Abrams Cone & Filling ability & $2-5 \mathrm{sec}$ \\
3 & T50cm slump flow & Passing ability & $0-10 \mathrm{~mm}$ \\
4 & J-ring & Filling ability & $6-12 \mathrm{sec}$ \\
5 & V-funnel & Passing ability & $0.8-1$ \\
6 & L-box & Segregation re- & $6-12,+3 \mathrm{sec}$ \\
\hline
\end{tabular}

\subsection{Hardened concrete test}

The compressive strength, tensile strength and flexural strength were calculated by the expressions shown below:

Compressive Strength for Cube $\left(f_{c k}\right)=\frac{P}{E}$

Tensile strength for cylinder $\left(f_{\mathrm{SP}}\right)=\frac{\vec{m}}{\mathrm{~m}}$

Flexural strength for prism $\left(f_{B}\right)=\frac{p}{t}$.

\section{Results and discussion}

\subsection{Fresh concrete test}

\subsubsection{Workability}

The slump flow test was performed using $1 \%$ and $4 \%$ SP with fly ash and ggbs for partial replacement of cement and plotted in Figure 1 .

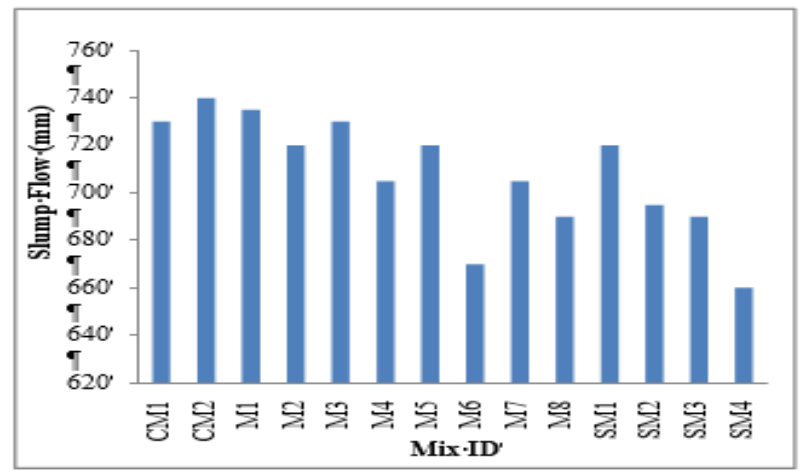

Fig. 1: Slump Flow Value of Control Mix and Partial Replacement of Cement with Fly Ash and GGBS Using 1\% and 4\% Sp.

From figure 1, the maximum slump flow was observed in control mix CM2 [100\% cement+1\% SP] with $740 \mathrm{~mm}$ slump flow. The mixes with super plasticizer content $1 \%$ gave lesser values when compared with the control mixes. The mix M1 (80\% cement $+20 \%$ fly ash) gave the best slump flow value of $735 \mathrm{~mm}$ as comparison to other mixes of waste materials. The least slump flow value was obtained at mix M6 $(50 \%$ cement $+50 \%$ ggbs) of $670 \mathrm{~mm}$. The mixes with super plasticizer $4 \%$ when compared with the control mixes gave less values of slump flow. The best slump flow was obtained at mix SM1 [cement $50 \%+$ fly ash $50 \%$ ] with a value of $720 \mathrm{~mm}$. As the percentage of waste materials increased the slump flow decreased. All the concrete mixes gave desirable slump flow value according to the EFNARC guidelines.

\subsubsection{Slump flow $\mathrm{t50} \mathrm{cm}$ test}

The Slump flow T50 $\mathrm{cm}$ test was performed using $1 \%$ and $4 \%$ SP with fly ash and ggbs for partial replacement of cement and plotted in Figure 2.

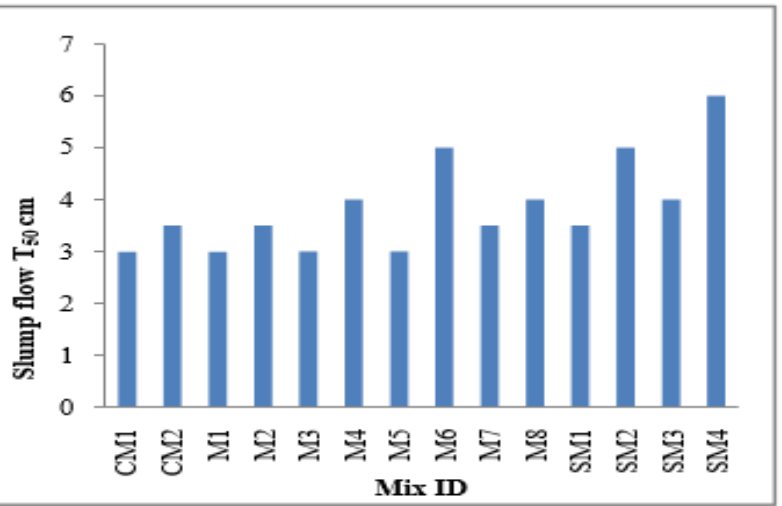

Fig. 2: Slump Flow T50 Cm Value of Control Mix and Partial Replacement of Cement with Fly Ash and GGBS Using 1\% and 4\% Sp.

The control mixes CM1 and CM2 had slump values of $3.5 \mathrm{sec}$ and $3 \mathrm{sec}$ respectively. The mix SM4 gave T50 CM value of 6 which is 
just higher limit according to the EFNARC standards. The best slump flow T50 cm values were observed in CM1, M5, M1 and M3, i.e 3 seconds. All the values were within the range of EFNARC guidelines except SM4.

\subsubsection{V-funnel values}

The V-Funnel test was performed using $1 \%$ and $4 \%$ SP with fly ash and ggbs for partial replacement of cement and plotted in Figure 3

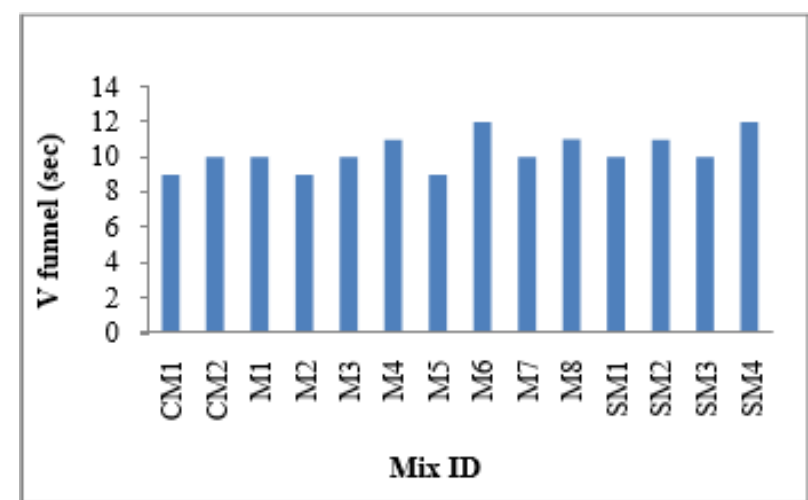

Fig. 3: V-Funnel Value of Control Mix and Partial Replacement of Cement with Fly Ash and GGBS Using $1 \%$ and $4 \%$ Sp.

From fig.3, it can be observed that the values for all mixes conducted in v-funnel test were within the range of EFNARC standards. The control mix CM1 and CM2 gave v-funnel value of $10 \mathrm{sec}$ and $9 \mathrm{sec}$ respectively. The maximum values of v-funnel were obtained in mixes M6, SM4 i.e. 12 seconds. The mixes of M6, SM4 contained higher level of ggbs percentage as compared fly ash or cement in volume of concrete.

\subsubsection{J-Ring values}

The J-Ring test was performed using $1 \%$ and $4 \%$ SP with flyash and ggbs for partial replacement of cementand plotted in figure 4

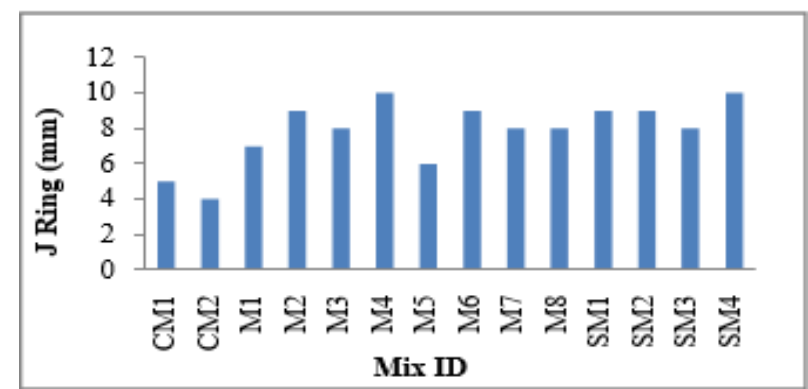

Fig. 4: J-Ring of Control Mix and Partial Replacement of Cement with Fly Ash and GGBS Using $1 \%$ and $4 \%$ Sp.

The J-ring test conducted on mixes and the values were obtained within the range of EFNARC standards. The least values of J-ring were obtained from the control mixes. The CM1 and CM2 gave $\mathrm{j}$ ring values of $5 \mathrm{~mm}$ and $4 \mathrm{~mm}$ respectively. The values of $\mathrm{j}$-ring increased with the increase in percentage of fly ash and ggbs in concrete. The maximum values of J-ring were obtained from mixes M4, SM3 which consisted of greater percentage of ggbs in comparison to fly ash in volume of concrete mix.

\subsubsection{L-box values}

The L-Box test was performed using $1 \%$ and $4 \%$ SP with fly ash and ggbs for partial replacement of cement and plotted in Fig. 5

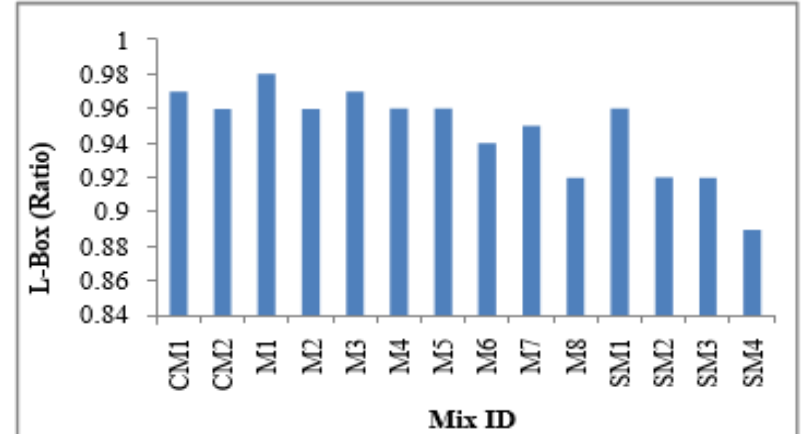

Fig. 5: L-Box of Control Mix and Partial Replacement of Cement with Fly Ash and GGBS Using $1 \%$ and $4 \%$ Sp.

The best values of L-box were obtained from the mix M1 [fly ash $20 \%+$ cement $80 \%$ ], i.e. 0.98 . The control mixes CM1 and CM2 also gave good ratio of L-box test of 0.96 and 0.97 respectively. If the concrete flows like water then the ratio of 1-box is consider as 1 and is the best flowing ability of fresh concrete properties. All the values satisfied the EFNARC guidelines.

\subsection{Hardened concrete test}

\subsubsection{Compressive strength}

Compressive strength test was conducted Partial Replacement of Cement with Fly Ash and ggbs using 1\% and 4\% SP and presented in Fig. 6.

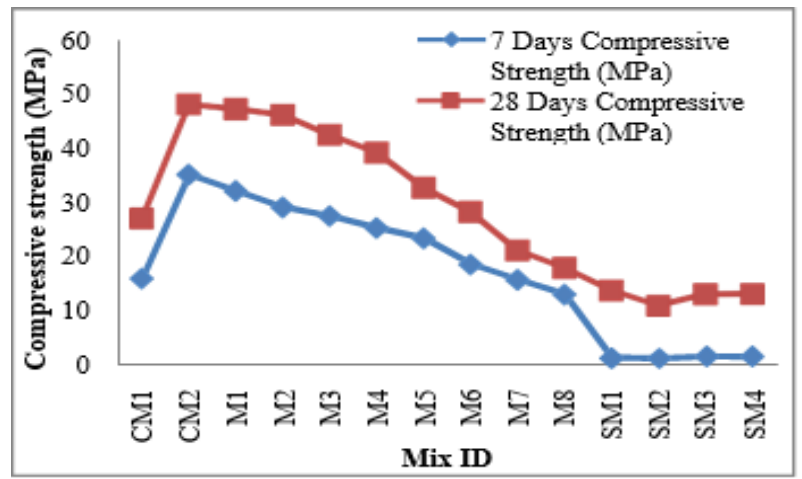

Fig. 6: 7 and 28 Days Compressive Strength Test Result of Control Mix And Partial Replacement of Cement with Fly Ash and GGBS Using 1\% and $4 \% \mathrm{Sp}$.

From the present study, it can be seen that the compressive strength of concrete decreased with increase in the percentage fly ash and ggbs content with partial replacement of cement for all days of water curing. The control mixes CM1 and CM2 gave compressive strength of $27.22 \mathrm{MPa}$ and $48.34 \mathrm{MPa}$ respectively in 28 days of water curing. The mix M1(cement $80 \%+$ fly ash $20 \%$ ) gave compressive strength of $47.28 \mathrm{MPa}$ in 28 days which was near to the value of control mix CM2.All other mixes of phase II shown a decreasing value of compressive as the percentage of waste materials increased in the SCC. The mixes with super plasticizer $4 \%$ and water to binder ratio 0.55 showed very low compressive strength in 7 days, (i.e. $1.41 \mathrm{MPa}, 1.24 \mathrm{MPa}, 1.62 \mathrm{MPa}$

and $1.57 \mathrm{MPa}$ for mixes SM1, SM2, SM3 and SM4 respectively) but drastic increase in percentage of compressive strength in 28 days after curing. The percentage of increase in compressive strength were $887.23 \%, 796.77 \%, 716.04 \%$ and $743.31 \%$ for the mix SM1, SM2, SM3 and SM4 respectively after 28 days of curing.

\subsubsection{Split tensile strength}

Split Tensile Strength test was conducted Partial Replacement of Cement with Fly Ash and ggbs using 1\% and 4\% SP and presented in Fig. 8 . 


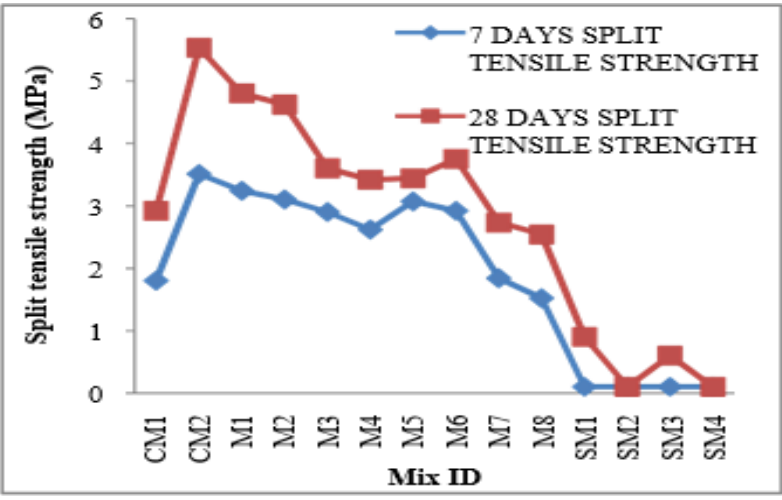

Fig. 7: 7 and 28 Days Split Tensile Strength Test Result of Control Mix and Partial Replacement of Cement with Fly Ash and Ggbs Using 1\% and 4\% Sp.

The maximum split tensile strength was obtained in the control mix CM2 after 7 days and 28 days of water curing, (i.e. $3.51 \mathrm{MPa}$ and 5.53MPa). The mix M1 obtained tensile strength of 3.24MPa and $4.8 \mathrm{MPa}$ in 7 days and 28 days. The mix with super plasticizer $4 \%$ does not showed any Split tensile strength in 7 days of curing. The mix SM1 and SM3 gave values of $0.90 \mathrm{MPa}$ and $0.60 \mathrm{MPa}$ after 28 days of curing.

\subsubsection{Flexural strength}

Flexural Strength test was conducted Partial Replacement of Cement with Fly Ash and ggbs using $1 \%$ and $4 \%$ SP and presented in Fig. 9

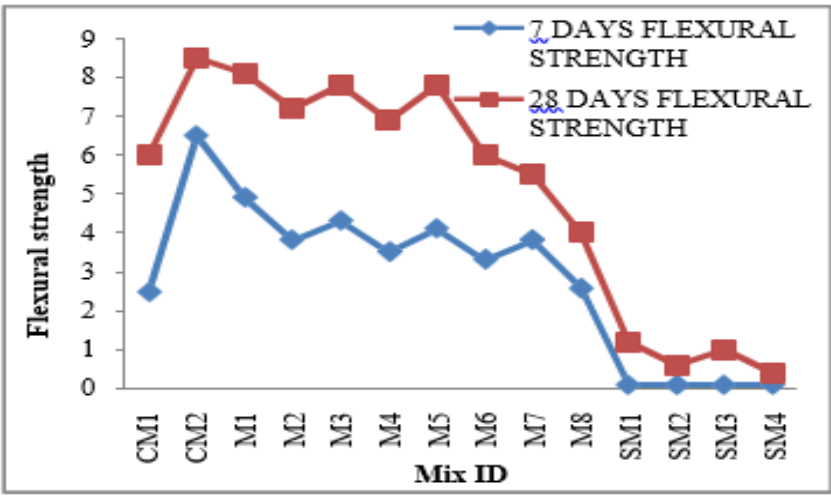

Fig. 8: 7 Days and 28 Days Flexural Strength Test Result of Control Mix And Partial Replacement of Cement with Fly Ash and GGBS Using 1\% and $4 \% \mathrm{Sp}$.

The maximum flexural strength was obtained in the control mix CM2 after 7 days and 28 days of water curing, (i.e. $6.5 \mathrm{MPa}$ and8.5MPa). The mix M1 gave flexural strength of $4.9 \mathrm{MPa} \&$ $8.1 \mathrm{MPa}$ at $7 \& 28$ days respectively. Nearly similar strengths were obtained in mix M1 \& CM2 after 28 days of curing. As the percentage of fly ash \& ggbs increased in volume of concrete, the flexural strength goes on decreasing at $7 \& 28$ days of water curing.

\section{Conclusions}

This paper addresses the experimental investigation on partial replacement of cement with fly ash and ggbs in SCC. Based on the experimental results, the following conclusions can be drawn: From the slump flow test it was observed that the slump flow decreased with increase in percentage of fly ash and ggbs in volume of concrete mix. The best slump flow value was obtained in control mix CM2. The lowest slump value was obtained in the mix SM4. In the present study, all mixes showed good slump value and are within the range of EFNARC standards.

The best slump flow T50 cm was observed in 4 mixes CM1, M1, M3 and M7 which is 3 seconds. Increasing percentage of ggbs in place of cement increases the slump flow T50 $\mathrm{cm}$ values. All mixes for slump flow T50cm values are within the range of EFNARC guidelines except SM4 (cement $40 \%+$ ggbs $40 \%+$ fly ash 20\%) mix. The SM4 had the slump flow T50cm of 6 seconds which is just higher than maximum limit of 5 seconds recommended in EFNARC standard of SCC.

The J-ring value was best in control mix CM1 (cement 100\%+ $0 \%$ $\mathrm{SP})$ with $4 \mathrm{~mm}$. The J-ring values increased with addition of fly ash and ggbs in volume of concrete as comparison to the control mixes. The L-box test results were performed well for all the mixes in the present study. The mix with greater slump flow value gave better results of L-box. All the mixes except SM4 satisfied the properties of fresh concrete as per EFNARC guidelines to qualify as self-compacting concrete.

Compressive strength values decreased with increase in percentage of waste materials in SCC mixes.

The maximum split tensile strength was observed in control mixture CM2. The split tensile strength values decreased with increase in percentage of waste materials (fly ash and ggbs) in the SCC mixes. The flexural strength values decreased with increase in percentage of waste materials (fly ash ggbs) in SCC mixes.

\section{Acknowledgements}

The authors would like to acknowledge the Department of Civil Engineering, Institute of Technical Education and Research, Siksha 'O' Anusandhan (Deemed to be University) Bhubaneswar, Odisha, for providing facilities for carrying out research work in related area.

\section{References}

[1] Xie Y, Liu B, Yin J and Zhou S (2002), Optimum mix parameters of high strength self-compacting concrete with ultra-pulverized fly ash. Cement and Concrete Research 32, 477-480.

[2] Cengiz DA (2005), Strength properties of high-volume fly ash roller compacted and workable concrete and influence of curing condition. Cement and Concrete Research. 35 1112-1121.

[3] Domone P (2007), a review of the hardened mechanical properties of self-compacting concrete. Cement and Concrete Composites 29, 1-12.

[4] Mustafa S and Yaman IO (2007) Transport and mechanical properties of self- consolidating concrete with high volume fly ash. Cement and Concrete Composites 31, 99-106.

[5] Khatib JM (2008), Performance of self-compacting concrete containing fly ash. Construction and Building Materials 22, 1963-1971. 